\title{
Molecular characterization of planktic cyanobacteria of Anabaena, Aphanizomenon, Microcystis and Planktothrix genera
}

\author{
Christina Lyra, ${ }^{1}$ Sini Suomalainen, ${ }^{2}$ Muriel Gugger, ${ }^{1} \dagger$ Chantal Vezie, ${ }^{1} \ddagger$ \\ Päivi Sundman, ${ }^{2}$ Lars Paulin $^{2}$ and Kaarina Sivonen ${ }^{1}$
}

1,2 Department of Applied Chemistry and Microbiology ${ }^{1}$ and Institute of

Biotechnology2, PO Box 56, Biocenter Viikki, 00014 Helsinki University, Finland
Author for correspondence: Kaarina Sivonen. Tel: +358 9 19159270. Fax: +358 919159322. e-mail: kaarina.sivonen@helsinki.fi

Toxic and non-toxic cyanobacterial strains from Anabaena, Aphanizomenon, Calothrix, Cylindrospermum, Nostoc, Microcystis, Planktothrix (Oscillatoria agardhii), Oscillatoria and Synechococcus genera were examined by RFLP of PCR-amplified 16S rRNA genes and 16S rRNA gene sequencing. With both methods, high 165 rRNA gene similarity was found among planktic, anatoxin-aproducing Anabaena and non-toxic Aphanizomenon, microcystin-producing and non-toxic Microcystis, and microcystin-producing and non-toxic Planktothrix strains of different geographical origins. The respective sequence similarities were $99 \cdot 9-100 \%, 94 \cdot 2-99 \cdot 9 \%$ and $99 \cdot 3-100 \%$. Thus the morphological characteristics (e.g. Anabaena and Aphanizomenon), the physiological (toxicity) characteristics or the geographical origins did not reflect the level of 165 rRNA gene relatedness of the closely related strains studied. In addition, cyanobacterial strains were fingerprinted with repetitive extragenic palindromic (REP)- and enterobacterial repetitive intergenic consensus (ERIC)-PCR. All the strains except two identical pairs of Microcystis strains had different band profiles. The overall grouping of the trees from the 16S rRNA gene and the REP- and ERIC-PCR analyses was similar. Based on the $16 S$ rRNA gene sequence analysis, four major clades were formed. (i) The clade containing filamentous heterocystous cyanobacteria was divided into three discrete groups of AnabaenalAphanizomenon, Anabaena/Cylindrospermum/ Nodularia/Nostoc and Calothrix strains. The three other clades contained (ii) filamentous non-heterocystous Planktothrix, (iii) unicellular non-heterocystous Microcystis and (iv) Synechococcus strains.

Keywords: cyanobacteria, 16S rRNA gene, RFLP, sequencing, REP, ERIC

\section{INTRODUCTION}

The chlorophyll- $a$-containing photosynthetic cyano-

\footnotetext{
†Present address: Laboratoire de Cryptogamie, Muséum National d'Histoire Naturelle, 12 rue Buffon, 75005 Paris, France.

¥Present address: Université de Rennes 1, UMR 6553 Ecobio, Campus de Beaulieu, Bat 14, Avenue du General Leclerc, 35042 Rennes Cedex, France.

Abbreviations: ERIC, enterobacterial repetitive intergenic consensus; LTRR, long tandemly repeated sequence; ML, maximum-likelihood; MP, maximum-parsimony; NJ, neighbour-joining; REP, repetitive extragenic palindromic; STRR, short tandemly repeated sequence; UPGMA, unweighted pairs group method with averages.

The GenBank/EMBL accession numbers for the cyanobacterial 16S rRNA gene sequences are AJ133151-AJ133154, AJ133156, AJ133157, AJ133159AJ133170, AJ133172-AJ133176 and AJ133185
}

bacteria occur in a wide range of habitats. In eutrophic fresh and brackish waters cyanobacteria form toxic water blooms which have caused human and animal poisonings (Ressom et al., 1994; Kuiper-Goodman et al., 1999). The most frequently found toxins in cyanobacterial blooms worldwide are hepatotoxic cyclic peptides, microcystins and nodularins (Sivonen \& Jones, 1999). Mass occurrences of cyanobacteria that contain neurotoxins [anatoxin-a, anatoxin-a(S) and saxitoxins] have been found in Australia, Europe and North America (Sivonen \& Jones, 1999).

Cyanobacteria are a morphologically diverse group of organisms ranging from unicellular to filamentous forms. Traditionally, the classification of cyanobacteria has been based on morphological characters, 
Table 1 Cyanobacterial strains used in this study

Toxin production is indicated as: $\mathrm{N}$, neurotoxic (anatoxin-a); $\mathrm{H}$, hepatotoxic (microcystins); NT, non-toxic; ND, toxicity not determined; NK; type of toxicity is not known. The strains for which toxicities are determined in this study are indicated in bold. The accession numbers of 16S rRNA genes indicated in the table are for sequences determined in this study. Culture collections: PCC, Pasteur Culture Collection, Paris, France; NIVA-CYA, Norwegian Institute for Water Research, Oslo, Norway; NIES, National Institute for Environmental Studies, Tsukuba, Japan. Aphanizomenon gracile PH-219 and Aphanizomenon sp. PH-271 were kindly provided by P. Henriksen (National Environmental Research Institute, Denmark), Microcystis sp. HUB5-3 by J. Fastner (Umwelt Bundes Amt, Germany) and Nostoc sp. 268 by B. Gromov (University of St Petersburg, Russia). References: 1, Asayama et al. (1996); 2, Giovannoni et al. (1988); 3, Herdman et al. (1979a); 4, Herdman et al. (1979b); 5, Kenyon et al. (1972); 6, Kondo et al. (2000); 7, Lachance (1981); 8, Leeuwangh et al. (1983); 9, Lehtimäki et al. (2000); 10, Lu et al. (1997); 11, Luukkainen et al. (1993); 12, Luukkainen et al. (1994); 13, Lyra et al. (1997); 14, Masephol et al. (1996); 15, Mazel et al. (1990); 16, Neilan et al. (1995); 17, Neilan et al. (1997a); 18, Neilan et al. (1997b); 19, Neilan et al. (1999); 20, Otsuka et al. (1999); 21, Rapala et al. (1993); 22, Rasmussen \& Svenning (1998); 23, Rippka \& Herdman (1992); 24, Rippka et al. (1979); 25, Rouhiainen et al. (1995); 26, Rudi \& Jakobsen (1999); 27, Rudi et al. (1997); 28, Rudi et al., 1998; 29, Sivonen et al. (1989); 30, Sivonen et al. (1990); 31, Sivonen et al. (1992); 32, Sivonen et al. (1995); 33, Turner (1997); 34, Turner et al. (1999); 35, Vezie et al. (1998); 36, Wilmotte (1994); 37, Wilmotte et al. (1992); 38, Yasuno et al. (1998).

\begin{tabular}{|c|c|c|c|c|}
\hline Strain & Toxicity & Geographical origin & Accession no. & Reference \\
\hline \multicolumn{5}{|l|}{ Anabaena sp. } \\
\hline 14 & $\mathrm{~N}^{*}$ & Lake Sääksjärvi, Finland & AJ133152 & $13,17,21,25,29$ \\
\hline 37 & $\mathrm{~N}^{*}$ & Lake Sääksjärvi, Finland & - & $13,25,29$ \\
\hline 54 & $\mathrm{~N}^{*}$ & Lake Sääksjärvi, Finland & - & $13,19,25,29$ \\
\hline 86 & $\mathrm{~N}^{*}$ & Lake Villikkalanjärvi, Finland & AJ133151 & $13,25,29$ \\
\hline 123 & $\mathrm{~N}^{*}$ & Lake Säyhteenjärvi, Finland & - & $13,19,25,29$ \\
\hline 130 & $\mathrm{~N}^{*}$ & Lake Säyhteenjärvi, Finland & - & $13,21,25$ \\
\hline $66 \mathrm{~A}$ & $\mathrm{H}^{*}$ & Lake Kiikkara, Finland & AJ133157 & $13,19,25,31-32$ \\
\hline $66 \mathrm{~B}$ & $\mathrm{H}^{*}$ & Lake Kiikkara, Finland & - & $13,25,31-32$ \\
\hline 90 & $\mathrm{H}^{*}$ & Lake Vesijärvi, Finland & AJ133156 & $13,19,25,31-32$ \\
\hline $202 \mathrm{~A} 1$ & $\mathrm{H}^{*}$ & Lake Vesijärvi, Finland & AJ133159 & $13,19,25,31-32$ \\
\hline $202 \mathrm{~A} 1 / 35$ & $\mathrm{H}^{*}$ & Lake Vesijärvi, Finland & - & 13 \\
\hline $202 \mathrm{~A} 2$ & $\mathrm{H}^{*}$ & Lake Vesijärvi, Finland & - & $13,25,31-32$ \\
\hline 277 & NT††S & River Perniönjoki, Finland & AJ133160 & $13,19,25$ \\
\hline РCC 6309 & $\mathrm{NT} \$ \S \Phi$ & Freshwater, The Netherlands & - & $3-5,7,23-24$ \\
\hline PCC 7108 & NTtף & Intertidal zone, USA & AJ133162 & $7,16,23-24$ \\
\hline PCC 73105 & NTt\$ & Pond water, England & - & $23,16,18$ \\
\hline РCC 9208 & NTtब & Soil, Spain & - & 23 \\
\hline \multicolumn{5}{|l|}{ Anabaena circinalis } \\
\hline NIES 41 & ND & Lake Kasumigaura, Japan & - & 16,18 \\
\hline \multicolumn{5}{|l|}{ Anabaena cylindrica } \\
\hline PCC 7122 & $\mathrm{NT} \$ \S \uparrow$ & Pond water, England & - & $2-4,7,13,23-24,33-34,36-37$ \\
\hline \multicolumn{5}{|l|}{ Anabaena flos-aquae } \\
\hline NIVA-CYA 83/1 & $\mathrm{H}^{*}$ & Lake Edlandsvatn, Norway & - & $9,13,19,25-28,31-32$ \\
\hline NIES 73 & NTtף & Lake Kasumigaura, Japan & - & 16,18 \\
\hline \multicolumn{5}{|l|}{ Anabaena spiroides } \\
\hline NIES $79^{\circ}$ & ND & Lake Kasumigaura, Japan & - & \\
\hline \multicolumn{5}{|l|}{ Aphanizomenon sp. } \\
\hline TR183 & $\mathrm{NT} \dagger+\$ \Phi$ & The Baltic Sea & - & $9,13,19$ \\
\hline 202 & $\mathrm{NT}+\mathrm{t}+\mathrm{Q}$ & Lake Vesijärvi, Finland & AJ133153 & 13,19 \\
\hline PH-271 & NT\$S & Lake Madesø, Denmark & - & \\
\hline PCC 7905 & NT\$\$ & Lake Brielse Meer, The Netherlands & AJ133154 & $9,13,16,23$ \\
\hline \multicolumn{5}{|c|}{ Aphanizomenon flos-aquae } \\
\hline NIES 81 & $\mathrm{NT \dagger} \dagger \S \| \uparrow$ & Lake Kasumigaura, Japan & & $16,18-19$ \\
\hline \multicolumn{5}{|l|}{ Aphanizomenon gracile } \\
\hline PH-219 & $\mathrm{NT} \$ \S \Phi$ & Lake Nørre, Denmark & - & \\
\hline \multicolumn{5}{|l|}{ Calothrix sp. } \\
\hline PCC 7714 & $\mathrm{NT} \$ \S \Phi$ & Pool, India & AJ133164 & 7,23 \\
\hline \multicolumn{5}{|c|}{ Cylindrospermum stagnale } \\
\hline PCC 7417 & $\mathrm{NT}+\$ \Phi$ & Soil, greenhouse, Sweden & AJ133163 & $3-4,7,23-24,33-34,36-37$ \\
\hline \multicolumn{5}{|l|}{ Nodularia spumigena } \\
\hline PCC $74301 / 1$ & $\mathrm{NT} \$ \S \Phi$ & Soil, Canada & - & $9,13,23$ \\
\hline \multicolumn{5}{|l|}{ Nostoc sp. } \\
\hline 152 & $\mathrm{H}^{*}$ & Lake Sääksjärvi, Finland & AJ133161 & $13,19,25,30$ \\
\hline 159 & NTt\$ & Lake Haukkajärvi, Finland & - & 28 \\
\hline
\end{tabular}


Table 1 (cont.)

\begin{tabular}{|c|c|c|c|c|}
\hline Strain & Toxicity & Geographical origin & Accession no. & Reference \\
\hline 268 & $\mathrm{NT}+\mathrm{t} \Phi$ & Unknown, Russia & - & $13,19,22,25$ \\
\hline PCC 6719 & 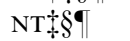 & Soil water culture, USA & - & $3-5,7,13,15,23-24$ \\
\hline PCC 7120 & $\mathrm{NT \dagger} \dagger \& \| \uparrow$ & Unknown, USA & - & $\begin{array}{l}1,3-4,7,9-10,13-15,19,22-25 \\
27-28,33-34,36\end{array}$ \\
\hline \multicolumn{5}{|l|}{ Nostoc punctiforme } \\
\hline PCC 73102 & $\mathrm{NT} \dagger \mathrm{t} \& \|$ & Macrozamia sp., Australia & - & $\begin{array}{l}2-4,7,13,15-16,18-19,22-24, \\
33-34,36\end{array}$ \\
\hline \multicolumn{5}{|l|}{ Microcystis sp. } \\
\hline 130 & $\mathrm{NT} \dagger+\$ \Phi$ & Lake Säyhteenjärvi, Finland & AJ133170 & 19,25 \\
\hline 199 & $\mathrm{H}^{*}$ & Lake Rusutjärvi, Finland & AJ133172 & $12,19,25,32$ \\
\hline 205 & $\mathrm{H}^{*}$ & Lake Mallusjärvi, Finland & - & $12,19,25,32$ \\
\hline 265 & NT†t\& & Lake Tuusulanjärvi, Finland & - & 25 \\
\hline 269 & $\mathrm{NT}+\mathrm{t} \& \mathrm{~S}$ & River Raisionjoki, Finland & AJ133175 & 19,25 \\
\hline GL060916 & $\mathrm{NT}+\delta 9$ & Lake Grand-Lieu, France & - & 35 \\
\hline GL260735 & 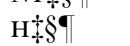 & Lake Grand-Lieu, France & - & 35 \\
\hline GL280641 & NT+\$ & Lake Grand-Lieu, France & AJ 133173 & 35 \\
\hline HUB5-3 & $\mathrm{NT} \dagger+\& \| \top$ & Lake Pehlitzee, Germany & - & 19 \\
\hline PCC 7005 & $\mathrm{NT}+\mathrm{t} \& \| \oplus$ & Lake Mendota, USA & - & $3-4,7,16-19,23-24,33$ \\
\hline \multicolumn{5}{|l|}{ Microcystis aeruginosa } \\
\hline PCC 7941 & 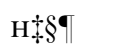 & Lake Little Rideau, Canada & - & $9,13,16-18,23,28,33-34$ \\
\hline NIES 44 & $\mathrm{NT}+\mathbf{T}$ & Lake Kasumigaura, Japan & - & $16,18,20$ \\
\hline NIES 89 & $\mathrm{H} \dagger+\delta \uparrow$ & Lake Kawaguchi, Japan & - & $6,16-18,33,38$ \\
\hline NIES 98 & $\mathrm{NT}+\mathrm{\dagger}+\mathrm{S}$ & Lake Kasumigaura, Japan & - & $6,16-18,33,38$ \\
\hline \multicolumn{5}{|l|}{ Microcystis viridis } \\
\hline NIES 102 & $\mathrm{H} \dagger \dagger \& \| \oplus$ & Lake Kasumigaura, Japan & - & $6,16-19,33,38$ \\
\hline \multicolumn{5}{|l|}{ Microcystis wesenbergii } \\
\hline NIES 104 & $\mathrm{NT} \dagger \mathrm{S}$ & Freshwater, Japan & AJ133174 & $6,20,38$ \\
\hline \multicolumn{5}{|l|}{ Planktothrix sp. } \\
\hline $1 / 1$ & $\mathrm{NT} \dagger+\S$ & Lake Långsjön, Finland & - & 13,25 \\
\hline 2 & $\mathrm{NT}+\mathrm{t} \& \mathrm{~S}$ & Lake Markusbölefjärden, Finland & AJ133185 & $13,19,25$ \\
\hline 18 & $\mathrm{NT \dagger}+\S$ & Lake Långsjön, Finland & - & $13,25,32$ \\
\hline 27 & NT†t\& & Lake Långsjön, Finland & - & 13,25 \\
\hline 28 & NT†t\& & Lake Markusbölefjärden, Finland & AJ133165 & 13 \\
\hline 45 & NT†† & Lake Enäjärvi, Finland & - & 13,25 \\
\hline 49 & $\mathrm{H}^{*}$ & Lake Valkjärvi, Finland & AJ133167 & $11,13,19,25,32$ \\
\hline 97 & $\mathrm{H}^{*}$ & Lake Maarianallas, Finland & - & $11,13,19,25,32$ \\
\hline NIVA-CYA 126 & $\mathrm{H}^{*}$ & Lake Långsjön, Finland & AJ133166 & $11,13,19,25,32$ \\
\hline NIVA-CYA 127 & $\mathrm{H}^{*}$ & Lake Vesijärvi, Finland & AJ133168 & 11,32 \\
\hline NIVA-CYA $128 / \mathrm{R}$ & $\mathrm{H}^{*}$ & Lake Vesijärvi, Finland & AJ133169 & $11,13,19,32$ \\
\hline \multicolumn{5}{|l|}{ Oscillatoria agardhii } \\
\hline PCC 7805 & $\mathrm{NK} \dagger+\S \Phi$ & Lake Veluwemeer, The Netherlands & - & $3-4,8-9,13,23$ \\
\hline NIES 204 & $\mathrm{H}+\S \|+\uparrow$ & Lake Kasumigaura, Japan & - & $16,18-19,33$ \\
\hline \multicolumn{5}{|l|}{ Oscillatoria acuminata } \\
\hline PCC 6304 & $\mathrm{NT} \$ \$ \uparrow$ & Source unknown & - & $2-5,23-24,33,36-37$ \\
\hline \multicolumn{5}{|l|}{ Oscillatoria sancta } \\
\hline PCC 7515 & NTt\$ & Greenhouse water tank, Sweden & - & $2-4,23-24,33-34,36-37$ \\
\hline \multicolumn{5}{|l|}{ Synechococcus sp. } \\
\hline GL150636 & NT屯\$ & Lake Grand-Lieu, France & AJ133176 & 35 \\
\hline
\end{tabular}

* Anatoxin-a or microcystin(s) have been characterized.

$\dagger$ Toxicity of the strain has been determined by mouse bioassay or another bioassay.

$\$$ Anatoxin-a has been screened by HPLC.

$\S$ Microcystins have been screened by HPLC.

\| Toxic compounds have been screened by a protein phosphatase inhibition assay.

- Hepatotoxicity of the strain has been screened by ELISA.

which can vary in different environmental or growth conditions and even be lost during cultivation. Komárek \& Anagnostidis (1989) have estimated that more than $50 \%$ of the strains in the culture collections have taxonomic names which do not agree with the morphological description of the taxon. 
The phenotypic and genotypic classification of cyanobacteria relies mainly on the studies of Stanier and collaborators (Kenyon et al., 1972; Herdman et al., 1979a, b; Rippka et al., 1979). Recent studies using 16S rRNA gene sequencing have extended the knowledge of the phylogenies of microcystin- and nodularinproducing, planktic Microcystis (Neilan et al., 1997a; Otsuka et al., 1998) and Nodularia (Lehtimäki et al., 2000) strains. The two genera, comprising both toxic and non-toxic strains, were found to be very homogeneous (Neilan et al., 1997a; Lehtimäki et al., 2000). In addition, partial sequencing of the variable region of the 16S rRNA gene has revealed planktic nonheterocystous Planktothrix (Oscillatoria agardhii) as well as Microcystis strains to be closely related (Rudi et al., 1997). Neurotoxic Anabaena and non-toxic Aphanizomenon strains have recently been found to form a tight group by an RFLP study of the total $16 \mathrm{~S}$ rRNA gene (Lyra et al., 1997). More 16S rRNA gene variability has been observed among the planktic Anabaena and Nostoc strains (Lyra et al., 1997; Rudi et al., 1997). Furthermore, strains belonging to the genus Synechococcus are highly divergent and are widely scattered across the evolutionary tree of cyanobacteria (Turner, 1997; Honda et al., 1999; Turner et al., 1999).

Although the 16S rRNA molecule contains variable regions (Woese, 1987), it is too well conserved for studying species identity (Fox et al., 1992) or intraspecies variation (Ward et al., 1992). Techniques that are based on highly repetitive sequences have been used for identification of toxic, planktic Anabaena, Nostoc (Rouhiainen et al., 1995) and Cylindrospermopsis (Wilson et al., 2000) strains. Furthermore, fingerprinting of the repetitive extragenic palindromic (REP) elements and/or enterobacterial repetitive intergenic consensus (ERIC) sequences has been used for identification of symbiotic (Rasmussen \& Svenning, 1998) and free-living cyanobacteria (Rasmussen \& Svenning, 1998; Lehtimäki et al., 2000).

We have isolated planktic anatoxin-a (Sivonen et al., 1989), microcystin-producing (Luukkainen et al., 1993, 1994; Sivonen et al., 1992, 1990, 1995; Vezie et al., 1998) and non-toxic cyanobacterial strains from fresh (Finnish and French) and brackish waters and purified them axenically (Rouhiainen et al., 1995). In this study, we characterized microcystin-producing Anabaena, Nostoc, Planktothrix (Oscillatoria agardhii) and Microcystis strains, that belong to six known microcystin producing genera (Sivonen \& Jones, 1999), by RFLP and sequencing of the 16S rRNA gene, and by REP- and ERIC-PCR. In addition, anatoxin-aproducing Anabaena strains, as well as non-toxic Anabaena, Aphanizomenon, Calothrix, Cylindrospermum, Nostoc, Planktothrix, Oscillatoria and Synechococcus strains were investigated.

\section{METHODS}

Cyanobacterial strains. The strains investigated are listed in Table 1. Non-nitrogen-fixing strains were grown in Z8 medium containing nitrogen (Kotai, 1972) whereas nitrogen-fixing strains were grown without nitrogen. The nitrogen-fixing Nodularia strain was grown in Z8 medium with salt and without nitrogen (Lehtimäki et al., 1994). The laboratory-cultured strains were characterized by the morphological criteria of Starmach (1966) and Tikkanen (1986). Nostoc sp. strain 152 and Microcystis sp. strains were identified only to genus level (Sivonen et al., 1990; Luukkainen et al., 1994). Neurotoxic Anabaena and nontoxic Aphanizomenon strains were distinguished by the typical characteristics of the latter genus, e.g. the hyaline elongated cells at the extremities of the trichomes and the flake-like bundles of the parallel trichomes as listed in Castenholtz (1989). The subsequent morphological identification of the neurotoxic Anabaena and the non-toxic Aphanizomenon strains placed these strains into the Anabaena flos-aquae/circinalis/mendotae (Sivonen et al., 1989; Rapala et al., 1993) and the Aphanizomenon flosaquae/gracile species groups, respectively. The hepatotoxic Anabaena strains belonged into the Anabaena flos-aquae/ lemmermannii/circinalis species group (Sivonen et al., 1992). All Planktothrix strains have been classified as Oscillatoria agardhii (Luukkainen et al., 1993) and renamed recently as Planktothrix. Due to difficulties in identification (the same strains were given different names by two experts or the same expert identified certain strains differently when studied more than once) and the loss of the morphological characteristics of the cultures kept in laboratory, it was decided to use only the genus and specify the organisms by strain numbers.

Toxin analyses. The anatoxin-a content of a total number of 26 cyanobacterial strains (indicated in bold in Table 1) was determined by HPLC with a Hewlett Packard HP 1090. Anatoxin-a was extracted from $20 \mathrm{mg}$ lyophilized cyanobacteria with water under sonication (Braun Labsonic-U) on ice (10 min). Samples were filtered through GF 52 filters (Schleicher \& Schuell) and concentrated on Oasis $\mathrm{C}_{18}$ cartridges (Waters). Before concentration, the $\mathrm{pH}$ of the samples was adjusted to 10 with $0 \cdot 1 \mathrm{M} \mathrm{NaOH}$. The toxin was eluted with $100 \%$ methanol containing $0.01 \%$ trifluoroacetic acid. The samples were subsequently dried and dissolved in $1 \mathrm{ml} 10 \%$ methanol. Hepatotoxins were extracted from $10 \mathrm{mg}$ lyophilized cells with water under sonication $(10 \mathrm{~min})$. Samples were filtered and concentrated as above, without adjusting the $\mathrm{pH}$. Hepatotoxins were eluted with $100 \%$ methanol, dried and dissolved in $1 \mathrm{ml}$ $20 \%$ methanol. The toxin samples were subsequently filtered through a Gelman Acrodisc $(0.2 \mu \mathrm{m})$. Anatoxin-a and hepatotoxins were analysed by HPLC with a diode array detector at $230 \mathrm{~nm}$ and $238 \mathrm{~nm}$, respectively. The column for the detection of anatoxin-a was a Devosil ODS-5 column $(4.6 \times 150 \mathrm{~mm}$; Nomura Chemical). The mobile phase was methanol/0.01 mol ammonium chloride ${ }^{-1}, \mathrm{pH} 4(1: 9, \mathrm{v} / \mathrm{v}$; Harada et al., 1989). The column for the detection of hepatotoxins was a Hewlett Packard ODS Hypersil column $(4 \cdot 6 \times 100 \mathrm{~mm})$. The mobile phase was acetonitrile $/ 0 \cdot 01 \mathrm{~mol}$ ammonium acetate $1^{-1}(24: 76, \mathrm{v} / \mathrm{v}$; Krishnamurthy et al., 1986). The flow rates were $0.9 \mathrm{ml} \mathrm{min}-1$ for anatoxin-a and $1 \mathrm{ml} \mathrm{min}{ }^{-1}$ for hepatotoxins. The injection volumes were $25 \mu 1$. The toxins were identified by their retention times and UV spectra. Purified anatoxin-a and microcystins were used as standards. Hepatotoxins were analysed by using an ELISA EnviroGard Microcystins Plate Kit as described in 
the manufacturer's instructions (Strategic Diagnostics). Water extracts from lyophilized cyanobacteria (0.5$0 \cdot 8 \mathrm{mg} \mathrm{ml}^{-1}$ ) were used for the assay.

Extraction of DNA. Genomic DNA was extracted as described by Golden et al. (1988). DNA from Aphanizomenon, Nodularia and Planktothrix strains was extracted by a slightly modified method, with the addition of sucrose $(10 \%$, $\mathrm{w} / \mathrm{v})$ and lysozyme $\left(10 \mathrm{mg} \mathrm{ml}^{-1}\right)$ as described previously (Lehtimäki et al., 2000).

RFLP of the amplified 16S rRNA gene. The $1500 \mathrm{bp}$ fragments of 16S rRNA genes were amplified with primers fD1 and rD1 (Weisburg et al., 1991) by PCR as described by Lyra et al. (1997). Amplified products were digested with AluI, DdeI, HaeIII, HhaI, MboI, MspI and RsaI, according to Lyra et al. (1997). The restriction fragments were separated by electrophoresis in a $3 \%$ agarose gel. The patterns of the restriction fragments were documented with a video camera (Panasonic CCTV, model WW-BP500/G). The images of restriction fragments were analysed using GelCompar software (version 4; Applied Maths BVBA) with manual editing. The similarity matrix was calculated with the Dice (1945) coefficient. Validity of the tree based on pairwise genetic distance values of restriction fragment data (Nei \& Li, 1979; Nei, 1987) was estimated with the PHYLIP software package (Felsenstein, 1993). Four clustering techniques were used: unweighted pair-group method using arithmetic averages (UPGMA; Sneath \& Sokal, 1973), neighbour-joining (NJ; Saitou \& Nei, 1987), and Fitch and Kitsch methods of PHYLIP (Felsenstein, 1993).

Sequencing of $16 \mathrm{~S}$ rRNA gene. Amplification and sequencing of the 16S rRNA genes were performed in two parts, with primers $\mathrm{pA}-\mathrm{pF}^{\prime}$ and $\mathrm{pD}-\mathrm{pH}^{\prime}$ (Edwards et al., 1989). Sequencing was performed by either the solid phase (Hultman et al., 1991) automated ALF sequencer (Pharmacia) or the cyclic sequencing methods using the dye termination sequencing kit (Perkin Elmer) and an ABI PRISM 377XL DNA sequencer (Perkin Elmer).

The sequences were assembled and edited using the Xgap program of the Staden package (Bonfield et al., 1995) and aligned by using CLUSTAL W (Higgins \& Sharp, 1989). The sequences have been submitted to EMBL/GenBank and the accession numbers are listed in Table 1 .

Phylogenetic trees were constructed using the maximumparsimony (MP) and the distance version of maximumlikelihood (ML) methods of PHYLIP, 3.5c (Felsenstein, 1993). In addition, the $\mathrm{NJ}$ method of the TREECON software package (van de Peer \& de Wachter, 1994) was used for tree construction. The statistical significance of the branches was estimated by bootstrap analysis of the tree programs, involving the generation of 1000 trees. Distances for the NJ tree were estimated by the algorithm of Kimura (1980). The same method was also used to determine the distances of the DNA parsimony consensus tree, because it was not possible to calculate distances by the DNA parsimony program of PHYLIP.

REP- and ERIC-PCR. PCR reactions were carried out as described by Lehtimäki et al. (2000) with primers 1R-I and 2 (REP), and 1R and 2 (ERIC) (Versalovic et al., 1991). The REP- and ERIC-PCR profiles were analysed by GelCompar software with manual editing. The similarity matrix was calculated by the Dice (1945) coefficient. The tree was constructed by the UPGMA algorithm of the GelCompar program.

\section{RESULTS}

\section{RFLP of amplified 16S rRNA genes}

Forty-two cyanobacterial strains were analysed by RFLP of the amplified 16S rRNA gene. In addition, data of 26 strains from the previous publication (Lyra et al., 1997) were included in the tree construction. From a total of 68 axenic cyanobacterial strains 29 different genotypes were detected (Fig. 1). The NJ, UPGMA, Fitch and Kitsch methods from PHYLIP gave a congruent major grouping and therefore only the UPGMA dendrogram is presented (Fig. 1). The cophenetic correlation value of the similarity matrix was $92 \cdot 1 \%$, thus the matrix was reliably represented by the UPGMA dendrogram.

In the RFLP study, the cyanobacteria were divided into four main branches (Fig. 1). The first branch contained all of the heterocystous cyanobacteria with the exception of Calothrix sp. strain PCC 7714. This strain formed a second branch with Oscillatoria sancta PCC 7515 and highly similar neurotoxic, hepatotoxic or non-toxic Planktothrix strains. Oscillatoria acuminata PCC 6304 formed the third branch with highly similar hepatotoxic or non-toxic Microcystis strains. The fourth branch contained Synechococcus sp. strain GL150636 (Fig. 1).

The heterocystous cyanobacteria were divided into two distinct clusters. One contained all Anabaena and Aphanizomenon strains, with the exception of Anabaena flos-aquae NIES 73. Anabaena flos-aquae NIES 73 was located alternatively with other Anabaena NIES strains (UPGMA, Kitsch) or it remained outside both clusters containing heterocystous strains (NJ, Fitch). Neurotoxic Anabaena and non-toxic Aphanizomenon strains shared identical or very similar $16 \mathrm{~S}$ rRNA genotypes and grouped together. In addition, Anabaena cylindrica PCC 7122 and Anabaena sp. strains PCC 6309 and PCC 73105 shared identical RFLP patterns. Nostoc sp. strain 152 grouped with non-toxic Anabaena sp. strain 277. Anabaena flosaquae (lemmermannii) NIVA-CYA $83 / 1$ formed a group with the planktic, hepatotoxic and neurotoxic Anabaena species and the non-toxic Aphanizomenon strains isolated from Finnish, Danish and Japanese freshwaters and the Baltic Sea (Table 1). Planktic Anabaena circinalis NIES 41 and Anabaena spiroides NIES 79 grouped more loosely with the same cluster. The other cluster containing heterocystous strains was composed of Nostoc, Nodularia and Cylindrospermum strains. Nostoc sp. strains 268 and 159 grouped with Nostoc punctiforme PCC 71302.

The non-heterocystous cyanobacteria were divided into groups of unicellular Microcystis and filamentous Planktothrix (Oscillatoria agardhii) strains. Microcystis and Planktothrix strains from NIVA-CYA, NIES and PCC collections were very closely related to Microcystis and Planktothrix strains from our own culture collection. Microcystis as well as Planktothrix strains formed homogeneous groups. Three clustering techniques (Fitch, NJ, UPGMA) loosely grouped 


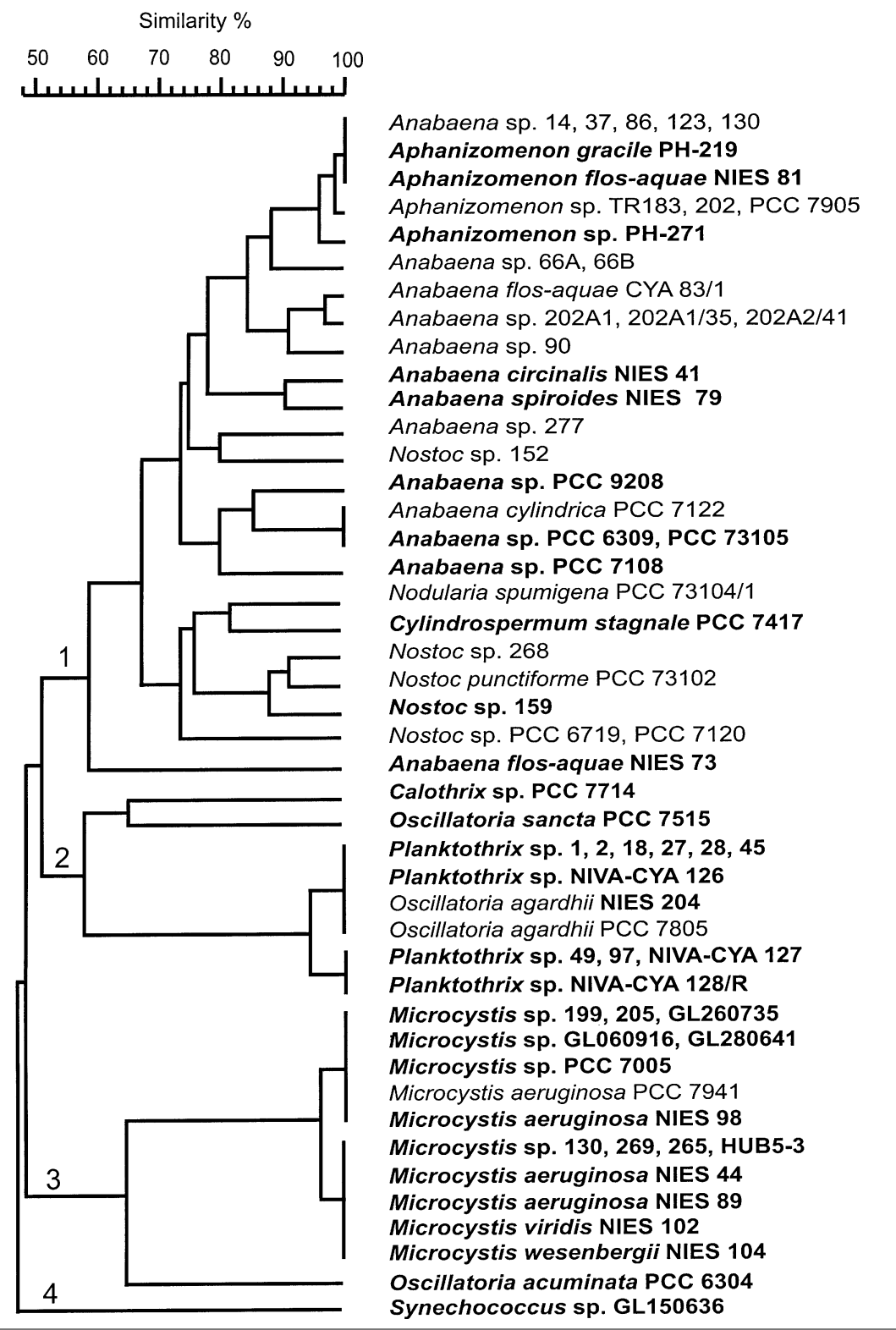

Fig. 1. UPGMA dendrogram based on RFLP of cyanobacterial $16 \mathrm{~S}$ rRNA genes. The strains analysed in this study are indicated in bold and the strains analysed by Lyra et al. (1997) in plain type. The scale bar represents the similarity coefficient (Dice, 1945) of restriction patterns of 16S rRNA genes. Numbers 1-4 indicate the four main clades found by RFLP analysis of $16 \mathrm{~S}$ rRNA gene. Symbols: 0 , neurotoxic; $\bigcirc$, non-toxic; $\mathbf{\square}$, hepatotoxic; $\square$, toxicity not determined; $\triangle$, type of toxicity not known.

Oscillatoria acuminata PCC 6304 with Microcystis strains, while four algorithms (Fitch, Kitsch, NJ, UPGMA) loosely grouped the filamentous heterocystous Calothrix sp. strain PCC 7714 with the Planktothrix strains and Oscillatoria sancta PCC 7515 (data not shown).

All four tree construction methods supported the inner branching of the groups containing strains of (i) neurotoxic Anabaena and non-toxic Aphanizomenon, (ii) hepatotoxic Anabaena and Anabaena NIVA-CYA 83/1, (iii) Anabaena from PCC, (iv) Nostoc PCC 73102, Nostoc 268 and 159, (v) Planktothrix and (vi) Microcystis strains (Fig. 1).

\section{Sequences of the 16S rRNA genes}

Nineteen representatives of the RFLP genotypes from Finnish lakes and the French Lake Grand-Lieu, and five strains from PCC and NIES were sequenced (Table 1). MP, ML and NJ methods were used to analyse 1425 (of 1442-1482) positions. The phylogenetic trees constructed by these methods were largely congruent and therefore only the NJ tree is presented (Fig. 2). However, bootstrap values for all methods are presented. The overall bootstrap values of the MP tree were lower than the values for ML and NJ trees. Most branches of the MP, ML and NJ trees were supported by high bootstrap values.

The cyanobacteria studied here were divided into four main branches (Fig. 2). The first branch constituted the filamentous cyanobacteria, Anabaena, Aphanizomenon, Nostoc, Nodularia, Cylindrospermum and Calothrix, capable of forming heterocysts and akinetes. The second branch contained non-heterocystous, filamentous Planktothrix strains. The third and fourth branches contained non-heterocystous 


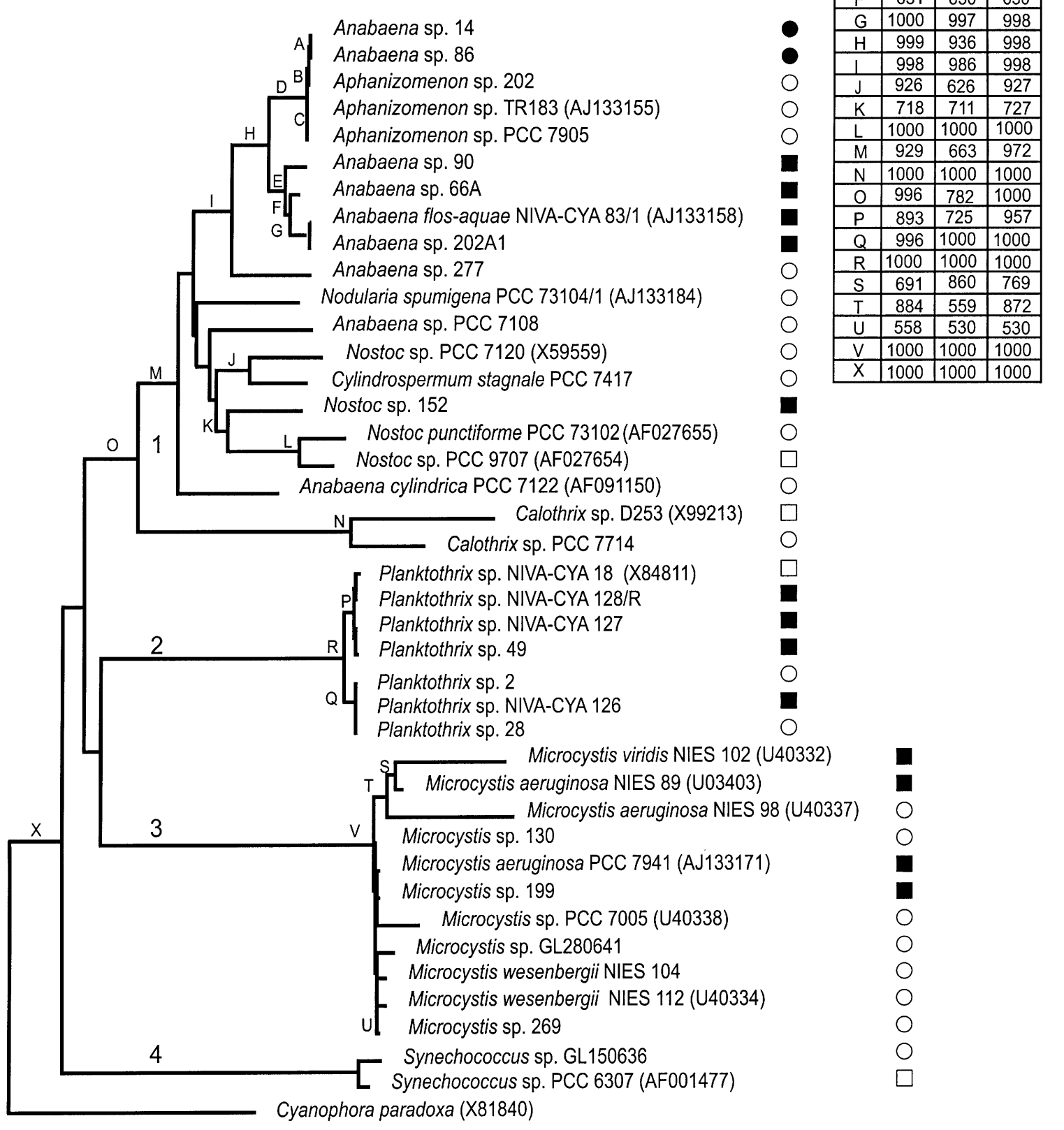

Fig. 2. Phylogenetic tree for cyanobacterial $16 S$ rRNA gene sequences. Bootstrap values higher than 500 are indicated in the table for ML, MP and NJ trees. The latter tree is presented. Scale bar represents $10 \%$ similarity of $1425 \mathrm{nt}$. EMBL accession numbers for the sequences are indicated in parentheses. Numbers 1-4 indicate the four main clades found by 16S rRNA gene sequence analysis. Symbols: $\bullet$, neurotoxic; $\bigcirc$, non-toxic; $\mathbf{\square}$, hepatotoxic; $\square$, toxicity not determined.

unicellular Microcystis and Synechococcus strains. The plastid Cyanophora paradoxa was chosen as an outgroup.
The 16S rRNA gene sequences of neurotoxic Anabaena sp. strains (14 and 86) were identical. The neurotoxic Anabaena and the non-toxic Aphanizomenon strains 
Similarity \%

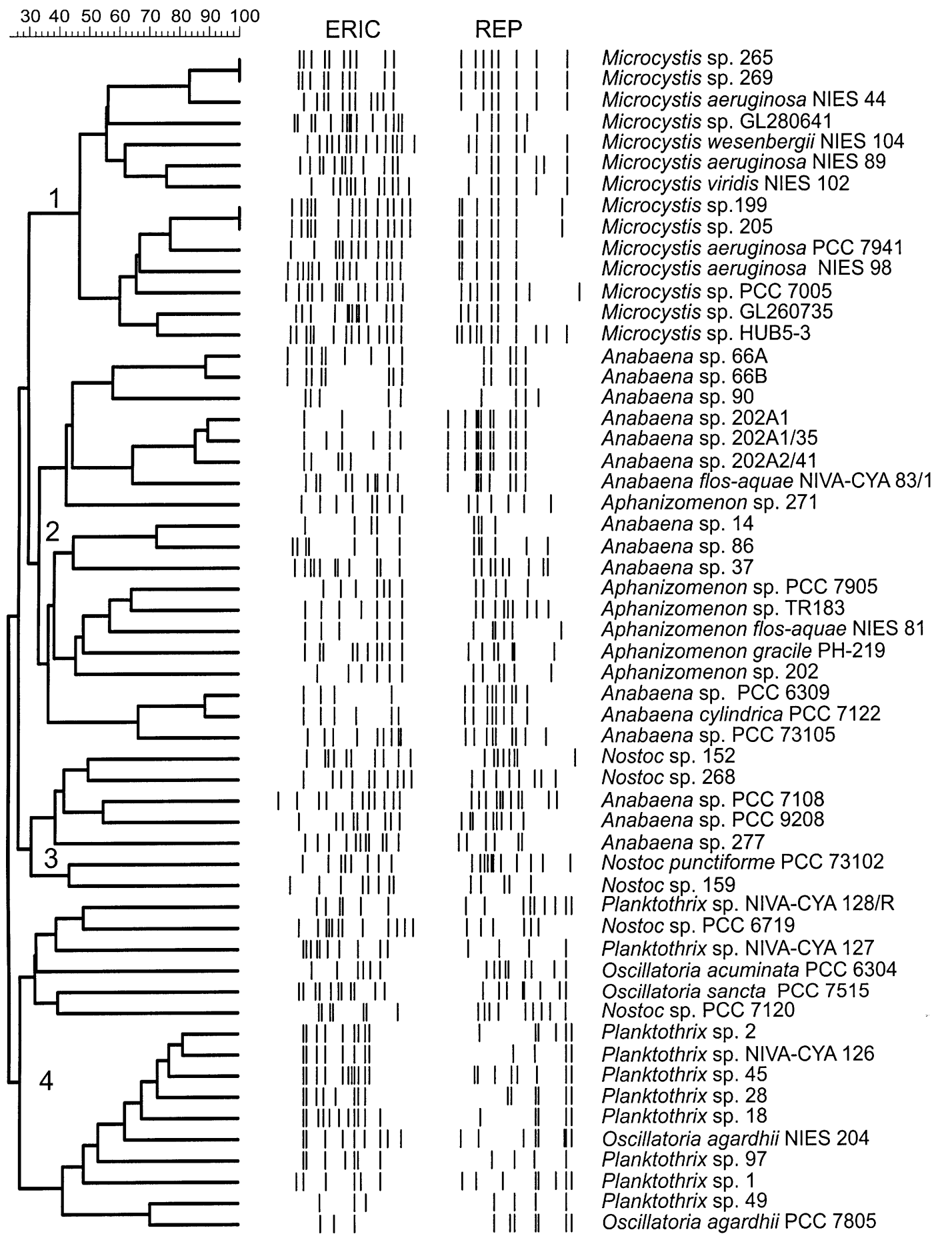

Fig. 3. UPGMA dendrogram based on cyanobacterial genomic fingerprints generated by REP- and ERIC-PCR. Scale bar represents the similarity coefficient (Dice, 1945) of the fingerprints of cyanobacterial strains. Numbers 1-4 indicate the four groups of cyanobacteria found by genomic fingerprinting. Symbols: $\boldsymbol{Q}$, neurotoxic; $\bigcirc$, non-toxic; $\mathbf{\square}$, hepatotoxic; $\square$, toxicity not determined; $\triangle$, type of toxicity not known.

shared remarkably high similarity values ranging from $99 \cdot 9$ to $100 \%$ and formed a tight group, which was supported by high bootstrap values in the MP, ML and NJ trees (Fig. 2). The similarity values within the Anabaena/Aphanizomenon cluster that also contained hepatotoxic and non-toxic Anabaena strains varied 
from 95.7 to $100 \%$. The non-toxic Anabaena 277 and the hepatotoxic Anabaena NIVA-CYA 83/1 shared the lowest similarity value within the Anabaena/ Aphanizomenon cluster.

Within the group comprising Nostoc, Cylindrospermum and Anabaena strains the 16S rRNA genes were more variable, sharing similarity values from 93.5 to $98 \%$. Nostoc sp. strain PCC 7120 and Cylindrospermum stagnale PCC 7417 grouped together, sharing $96.9 \% \quad 16 \mathrm{~S}$ rRNA gene similarity. Interestingly, Anabaena cylindrica PCC 7122 was outside the branches that contained other Anabaena, Aphanizomenon, Nostoc, Cylindrospermum and Nodularia strains in the trees constructed using ML and NJ methods, while this strain was loosely grouped with the Anabaena and Aphanizomenon strains in the MP tree. Similarly, Anabaena sp. strain PCC 7108 was found with the Anabaena/Aphanizomenon (ML, NJ) or with the cluster that contained strains belonging to several heterocystous genera (MP). Anabaena cylindrica PCC 7122 and the two branches that contained heterocystous strains shared similarity values from 94 to $95 \%$ and from 93.4 to $94.8 \%$, respectively. Anabaena PCC 7108 and these two clusters shared similarity values from $94 \cdot 1$ to $94.5 \%$ and from 93.8 to $95.8 \%$, respectively.

Calothrix strains were outside the other branches of heterocystous, filamentous cyanobacteria with similarity values less than $90 \cdot 2 \%$. The two Calothrix strains were moderately close relatives, sharing $95.1 \%$ sequence similarity.

Three branches of non-heterocystous Planktothrix, Microcystis and Synechococcus were found. Planktothrix and Microcystis strains formed two very homogeneous clusters. Within these clusters, the 16S rRNA gene sequence similarities varied from $99 \cdot 3$ to $100 \%$ and from 94.2 to $99.9 \%$, respectively. The two clusters of Microcystis and Planktothrix strains were as far apart from each other as from the clusters containing heterocystous strains (similarity values less than $89 \cdot 7 \%$ ). Synechococcus sp. strain GL150636 formed a distinct branch, sharing less than $86.7 \%$ sequence similarity with the strains sequenced. Synechococcus sp. strain GL150636 and Synechococcus sp. strain PCC 6307 shared $99 \cdot 2 \%$ similarity, indicating very close relatedness.

\section{REP and ERIC fingerprinting}

The strains belonging to the genera known to produce anatoxin-a or microcystins were chosen for REP- and ERIC-PCR analysis. Anabaena, Aphanizomenon, Microcystis and Planktothrix (Oscillatoria agardhii) genera, containing identical or highly similar strains, when analysed by RFLP or by sequencing of the $16 \mathrm{~S}$ rRNA genes were differentiated by REP- and ERICPCR. These methods gave highly reproducible fingerprints (data not shown). Tree construction by a UPGMA algorithm was possible, but the reliability of the cluster analysis was not high as shown by a low
(76.2\%) cophenetic correlation value. Fingerprinting differentiated all studied strains except two identical pairs of non-toxic Microcystis sp. strains 265 and 269 and toxic Microcystis sp. strains 199 and 205 (Fig. 3). Thus this method is suitable when high resolution is needed. Four clear clusters were formed: (i) Microcystis, (ii) Anabaena/Aphanizomenon, (iii) Nostoc/ Anabaena and (iv) Nostoc/Oscillatoria/Planktothrix group (Fig. 3). The Anabaena/Aphanizomenon group was divided into two subgroups.

\section{DISCUSSION}

Four major clades of cyanobacteria were found in the 16S rRNA gene analysis. Morphologically different neurotoxic Anabaena and non-toxic Aphanizomenon strains formed an extremely tight cluster, which was highly supported by bootstraps values of MP, ML and NJ trees. The grouping was also supported by RFLP analysis of the 16S rRNA gene and by REP and ERIC fingerprinting. Previously, molecular taxonomic studies have indicated the grouping of Anabaena together with Aphanizomenon strains (e.g. Neilan et al., 1995; Rudi et al., 1997; Lu et al., 1997; Lyra et al., 1997; Rudi \& Jakobsen, 1999), but in this study high similarity (more than $99.9 \%$ ) at the $16 \mathrm{~S}$ rRNA gene level was revealed.

Similarly, morphological differences between $O s$ cillatoria and Microcoleus genera (Wilmotte et al., 1992) and within the Merismopedia genus (Palinska et al., 1996) are not reflected at the 16S rRNA gene level. On the other hand, the unicellular cyanobacteria that are morphologically similar and simple can be phylogenetically different (Ward et al., 1992).

Generally, the 16S rRNA gene sequence and RFLP analysis gave similar results. In the RFLP study, Anabaena sp. strain PCC 7108 and Anabaena cylindrica PCC 7122 grouped with the cluster containing Anabaena and Aphanizomenon strains. In the sequence analysis, these strains grouped similarly (MP) or Anabaena PCC 7108 grouped with the Cylindrospermum, Nodularia and Nostoc strains while Anabaena cylindrica PCC 7122 reminded outside both of these clusters (ML, MP). The low bootstrap values of the branches containing Anabaena PCC 7108 and PCC 7122 strains as well as the shared similarity values between these strains and other nitrogen-fixing cyanobacteria indicate that these strains are as closely related to the Anabaena and Aphanizomenon as to the Cylindrospermum, Nodularia and Nostoc strains. In addition, Nostoc 152 can belong to both clusters, as shown by the different groupings of the strain in the 16S rRNA gene analyses and the shared similarity values of Nostoc 152 and the other nitrogen-fixing strains. The most distant heterocystous filamentous Calothrix species, strain PCC 7714, grouped with Oscillatoria sancta PCC 7515 when studied by RFLP. In sequence analysis, the Calothrix strains formed a distinct cluster. The disparity could be due to errors in the RFLP method caused by undetectable restriction 
fragments (small fragments) or fragment length differences.

The distances in the trees created by $16 \mathrm{~S}$ rRNA gene RFLP and sequencing revealed that the evolutionary relationships of the Cylindrospermum, Nostoc, Anabaena PCC 7108 and PCC 7122 strains are not clear. The low bootstrap values of the nodes within the cluster analysed by 16S rRNA gene sequencing are consistent with this result. Wilmotte (1994) and Turner (1997) have also reported the uncertain grouping of the strains belonging to these three genera by $16 \mathrm{~S}$ rRNA gene sequence analysis. Furthermore, an RFLP study of the $16 \mathrm{~S}-23 \mathrm{~S}$ rDNA spacer region has revealed that a subset of Nostoc strains grouped with a cluster containing Anabaena and Aphanizomenon, while the rest of the Nostoc strains formed a distinct subgroup with Anabaena strains PCC 7120 and ATCC 27892 (Lu et al., 1997). The latter strains have been proposed to belong to Nostoc genera by Rippka \& Herdman (1992).

Planktothrix strains isolated from the Finnish lakes shared very high $16 \mathrm{~S}$ rRNA gene sequence similarities $(99 \cdot 3-100 \%)$. The high similarity of the Planktothrix NIVA-CYA strains has been determined previously by Rudi et al. (1997). Our strains were highly similar to the Planktothrix sp. strain NIVA-CYA 18 and Oscillatoria agardhii NIES 204 strains, which have been placed into one of the five subgroups containing Oscillatoria strains (Turner, 1997). These two strains have been proposed to belong to the Planktothrix genus by Anagnostidis \& Komárek (1988). The redpigmented Planktothrix sp. strain NIVA-CYA 128/R was grouped tightly with green-pigmented Planktothrix strains. Previously, the red-pigmented NIVACYA $128 / \mathrm{R}$ strain was separated from green-pigmented Planktothrix strains by a phenotypic wholecell protein analysis (Lyra et al., 1997). Wilmotte et al. (1992) found that different pigment content and the presence and absence of chromatic adaptation did not correlate with significant divergence at the 16S rRNA gene level.

The remarkable 16S rRNA gene sequence similarity of 99.9-100\% of neurotoxic Anabaena and non-toxic Aphanizomenon strains indicate that these strains could be different phenotypes of the same species. However, the studies of Lachance (1981) revealed that two strains sharing as high as $99.8 \%$ rRNA gene similarity can share as little as $25 \%$ DNA-DNA reassociation and thus not belong to the same species. A species is generally defined as a group of strains if they share approximately $70 \%$ or greater DNA-DNA relatedness and $5^{\circ} \mathrm{C}$ or less $\Delta T_{\mathrm{m}}$, and if their phenotypic characteristics agree with this definition (Wayne et al., 1987).

Planktic Anabaena sp. strain 277 and the other planktic Anabaena and Aphanizomenon strains shared sequence homology of less than $96 \cdot 6 \%$. It is known that strains with $16 \mathrm{~S}$ rRNA gene sequence similarity values below $97.5 \%$ are unlikely to have more than $60-70 \%$ DNA similarity and that they are unlikely to belong to the same species (Stackebrandt \& Goebel, 1994). 16S rRNA gene sequence analysis is a superior method when the similarity values of strains are below $97 \%$. Thus Anabaena 277 may belong to a different species than the other planktic Anabaena and Aphanizomenon strains. Furthermore, planktic Anabaena and Aphanizomenon strains seem to be well diverged from Anabaena PCC 7108 and Anabaena cylindrica PCC 7122. The two latter strains are not closely related to each other, because the 16S rRNA gene sequence similarity value between them was only $93.5 \%$. Anabaena PCC 7108 and PCC 7122 have been found to share a DNA-DNA reassociation value of $32 \%$ (Lachance, 1981). This value was $94.6 \%$ between Anabaena strains PCC 7122 and PCC 6309 (Lachance, 1981). Their relatedness (as well as Anabaena sp. strain PCC 73105) at the species level was also shown here by the shared RFLP profile of the 16S rRNA gene. Thus, PCC 7122 and PCC 6309 may belong to the same species and PCC 7108 may belong to a different species. The $100 \%$ RFLP homology of the 16S rRNA gene between Anabaena sp. strains PCC 6309, PCC 7122 and PCC 73105 indicates that these strains may well belong to the Anabaena cylindrica species.

It seems that almost all strains within the heterogeneous Nostoc, as well as Calothrix, group represent individual species, because the similarity values of $16 \mathrm{~S}$ rRNA gene sequences within the group were below $97.5 \%$. In contrast, there seems to be no species variation inside the three homogeneous clusters containing Anabaena and Aphanizomenon strains, Planktothrix strains and Microcystis strains. The species classifications based on 16S rRNA genes are not supported on phenotypic grounds except in the case of Planktothrix. The Microcystis strains have been found to share high sequence similarities of the 16S rRNA gene (Otsuka et al., 1998) and of the 16S-23S internal transcribed spacer (Otsuka et al., 1999). Toxic and non-toxic Microcystis strains isolated from Finnish lakes were grouped tightly with Microcystis strains from PCC and NIES culture collections, which have been shown to belong to the major Microcystis cluster by $16 \mathrm{~S}$ rRNA gene analysis (Neilan et al., 1997a; Turner, 1997). In addition, the different Microcystis species as classified by morphological features observed microscopically, such as cell size, cell arrangements in colonies and the existence of gas vesicles (Komárek, 1991), have been found to integrate into one species in DNA-DNA reassociation and DNA base composition analyses (Kondo et al., 2000). It remains to be seen if the Anabaena and Aphanizomenon genera as distinguished by characteristics of the latter genus (Castenholtz, 1989) also share high levels of DNA-DNA relatedness.

The unicellular Synechococcus strains were as distantly related to the unicellular Microcystis genus as to the filamentous genera. Synechococcus sp. strain GL150636 from the French Lake Grand-Lieu was 
remarkably similar to the freshwater Synechococcus sp. strain PCC 6307, which has been found to belong to one of the polyphyletic branches that also contains marine Synechococcus and Prochlorococcus strains (Turner, 1997; Urbach et al., 1998; Honda et al., 1999). These branches also contain other unicellular or filamentous non-heterocystous strains (Turner, 1997; Honda et al., 1999).

In this study we have shown that REP and ERIC genomic fingerprinting allows quick determination and grouping of closely related strains. Furthermore, the number of fragments produced by REP and ERIC fingerprinting was adequate and it varied only moderately among studied strains, which made numerical analysis and tree construction possible. Closely related neurotoxic Anabaena and non-toxic Aphanizomenon strains, Microcystis strains and Planktothrix strains were differentiated to a high degree by REP and ERIC fingerprinting. The method even differentiated very similar strains of Anabaena (14 and 86), Aphanizomenon (TR183 and PCC 7905) and Planktothrix (49 and 127). The most striking feature was the grouping of the Nostoc sp. strains PCC 6719 and PCC 7120 with the Planktothrix strains. The DNA-DNA reassociation and RFLP studies of the 16S rRNA gene have shown that Nostoc PCC 6719 and PCC 7120 probably belong to the same species, since the strains share $96 \%$ DNA-DNA homology (Lachance, 1981) and $100 \%$ 16S rRNA gene RFLP homology (Lyra et al., 1997). In addition, these strains were found to be identical in the hybridization study with a short terminal repeated repetitive (STRR) sequence probe (Mazel et al., 1990). Good resolution of strains belonging to the symbiotic Nostoc (Rasmussen \& Svenning, 1998) and free-living Nodularia and Nostoc (Rasmussen \& Svenning, 1998; Lehtimäki et al., 2000) genera has also been obtained with REP and/or ERIC fingerprinting. REP and ERIC (Versalovic et al., 1991) fingerprinting is an excellent method when closely related, axenic strains are studied.

Previous Southern blot analysis and PCR fingerprinting revealed the existence of STRR sequences among genera that contain filamentous heterocystous strains (Mazel et al., 1990; Rouhiainen et al., 1995; Rasmussen \& Svenning, 1998; Wilson et al., 2000; Lehtimäki et al., 2000) or unicellular Microcystis (Asayama et al., 1996) strains. In addition, long tandemly repeated repetitive (LTRR) sequences have been used for characterization of mainly Nostoc strains (Masephol et al., 1996; Rasmussen \& Svenning, 1998). STRR and LTRR sequences appear to be superior when studying non-axenic cyanobacteria (Rasmussen \& Svennig, 1998; Lehtimäki et al., 2000).

In this study toxicity was not consistent with the genetic analysis of a wide range of cyanobacterial genera. Previously, Neilan et al. (1997a) found no correlation between 16S rRNA genes and the toxicity of Microcystis strains. This genotypic distinction between toxic and non-toxic cyanobacteria has been indicated by several genotypic analyses of Nodularia strains (Lehtimäki et al., 2000). The best way to differentiate toxic and non-toxic Microcystis/ Planktothrix/Anabaena strains might be to sequence the domains of peptide synthetases that are multienzyme complexes responsible for microcystin production (Neilan et al., 1999).

There was no geographical distribution pattern of specific genotypes among the freshwater cyanobacteria in this study. For example the Microcystis strains forming two identical pairs by REP- and ERIC-PCR were isolated from four different Finnish lakes. Cyanobacterial 16S rRNA gene sequences from the Pacific Ocean and the Atlantic Ocean isolates have revealed that some cyanobacterial strains are globally distributed (Giovannoni et al., 1990; Schmidt et al., 1991; Fuhrman et al., 1993; Mullins et al., 1995). In addition, Bolch et al. (1999) and Lehtimäki et al. (2000) have found very closely related cultured Nodularia strains from geographically separated areas.

The different topologies between trees based on cyanobacterial 16S rRNA genes and tRNA ${ }^{\text {Leu }}$ introns suggest that lateral gene transfer of these introns has occurred in cyanobacterial radiation (Rudi \& Jakobsen, 1999). In addition, comparisons of $16 \mathrm{~S}$ rRNA and $r b c L X$ (encoding D-ribulose-1,5-bisphosphate carboxylase-oxygenase large subunit and chaperonin-like protein) phylogenies indicate lateral DNA transfer among cyanobacteria (Rudi et al., 1998). Recently, it was stated that lateral gene transfer cannot be limited to special categories of genes (Doolittle, 1999). Even the most used and trusted chronometers, rRNA genes, can be transferred as shown by complete exchange of rRNA genes between bacteria (Asai et al., 1999). In this study, the overall agreement of the trees based on the 16S rRNA gene and REP and ERIC total genome fingerprinting showed that the 16S rRNA gene represents the total genome. In addition, the studies of Vinuesa et al. (1998) and Lehtimäki et al. (2000) revealed similar genotypic diversity of Bradyrhizobium and Nodularia strains by these two methods. The studies of whole-cell protein (the gene products representing the total genome) and RFLP of the 16S rRNA gene gave fairly congruent results (Lyra et al., 1997). Thus, lateral transfer of $16 \mathrm{~S}$ rRNA genes might not play a major role among the studied strains.

In summary, the trees based on the numerous full length 16S rRNA gene sequences have revealed four homogeneous groups of planktic strains: (i) non-toxic Aphanizomenon, anatoxin-a-producing Anabaena and hepatotoxin-producing Anabaena (this study); (ii) non-toxic and microcystin-producing Microcystis (Neilan et al., 1997a; Otsuka et al., 1998; this study); (iii) non-toxic and nodularin-producing Nodularia (Lehtimäki et al., 2000); and (iv) non-toxic and microcystin-producing Planktothrix (this study). Nontoxic strains belonging to Anabaena, Cylindrospermum and Calothrix, and non-toxic and hepatotoxin-producing strains belonging to Nostoc were more loosely related. 


\section{ACKNOWLEDGEMENTS}

We thank Dr Kaisa Haukka and Dr Jaana Lehtimäki for critical reading of the manuscript and Dr Sari Repka, Ms Luydmila Saari and Ms Minna Koivula for helping in toxin analyses. Dr Peter Henriksen is thanked for kindly providing two Danish Aphanizomenon strains and Dr Jutta Fastner for a Microcystis strain. The study was supported by grants from the Academy of Finland, the Helsinki University, Maj and Tor Nessling Foundation and the Centre for International Mobility (CIMO).

\section{REFERENCES}

Anagnostidis, K. \& Komárek, J. (1988). Modern approach to the classification system of cyanophytes 3-Oscillatoriales. Arch Hydrobiol Suppl 80 (Algol Stud 50/53), 327-472.

Asai, T., Zaporojets, D., Squires, C. \& Squires, C. L. (1999). An Escherichia coli strain with all chromosomal rRNA operons inactivated: Complete exchange of rRNA genes between bacteria. Proc Natl Acad Sci US A 96, 1971-1976.

Asayama, M., Kabasawa, M., Takahashi, I., Aida, T. \& Shirai, M. (1996). Highly repetitive sequences and characteristics of genomic DNA in unicellular cyanobacterial strains. FEMS Microbiol Lett 137, 175-181.

Bolch, C. J. S., Orr, P. T., Jones, G. J. \& Blackburn, S. I. (1999). Genetic, morphological, and toxicological variation among globally distributed strains of Nodularia (cyanobacteria). $J$ Phycol 35, 339-355.

Bonfield, J. K., Smith, K. F. \& Staden, R. (1995). A new DNA sequence assembly program. Nucleic Acids Res 24, 4992-4999.

Castenholz, R. W. (1989). Subsection IV. Order Nostocales. In Bergey's Manual of Systematic Bacteriology, vol. 3, pp. 1780-1793. Edited by J. T. Staley, M. P. Bryant, N. Pfenning \& J. G. Holt. Baltimore: Williams \& Wilkins.

Dice, L. R. (1945). Measures of the amount of ecological association between species. $J$ Ecol 26, 297-302.

Doolittle, W. F. (1999). Phylogenetic classification and the universal tree. Science 284, 2124-2128.

Edwards, U., Rogall, T., Blöcker, H., Emde, M. \& Böttger, E. C. (1989). Isolation and direct complete determination of entire genes. Characterization of a gene coding for $16 \mathrm{~S}$ ribosomal RNA. Nucleic Acids Res 17, 7843-7853.

Felsenstein, J. (1993). PHYLIP (Phylogeny Inference Package) version 3.5c. Seattle: Department of Genetics, University of Washington.

Fox, G. E., Wisotzkey, J. D. \& Jurtshuk, P., Jr. (1992). How close is close: $16 \mathrm{~S}$ rRNA sequence identity may not be sufficient to guarantee species identity. Int J Syst Bacteriol 42, 166-170.

Fuhrman, J. A., McCallum, K. \& Davis, A. A. (1993). Phylogenetic diversity of subsurface marine microbial communities from the Atlantic and Pacific Oceans. Appl Environ Microbiol 59, 1294-1302.

Giovannoni, S. J., Turner, S., Olsen, G. A., Barns, S., Lane, D. J. \& Pace, N. C. (1988). Evolutionary relationships among cyanobacteria and green chloroplasts. J Bacteriol 170, 3584-3592.

Giovannoni, S. J., Britschgi, T. B., Moyer, C. L. \& Field, K. G. (1990). Genetic diversity in Sargasso Sea bacterioplankton. Nature 345, 60-63.

Golden, J. W., Carrasco, C. D., Mulligan, M. E., Schneider, G. J. \& Haselkorn, R. (1988). Deletion of a 55-kilobase-pair DNA element from the chromosome during heterocyst differentiation of Anabaena sp. strain PCC 7120. J Bacteriol 170, 5034-5041.
Harada, K.-I., Kimura, Y., Ogawa, K., Suzuki, M., Dahlem, A. M., Beasley, V. R. \& Carmichael, W. W. (1989). A new procedure for the analysis and purification of naturally occurring anatoxin-a from the blue-green alga Anabaena flos-aquae. Toxicon 27, 1289-1296.

Herdman, M., Janvier, M., Waterbury, J. B., Rippka, R. \& Stanier, R. Y. (1979a). Deoxyribonucleic acid base composition of cyanobacteria. J Gen Microbiol 111, 63-71.

Herdman, M., Janvier, M., Rippka, R. \& Stanier, R. Y. (1979b). Genome size of cyanobacteria. J Gen Microbiol 111, 73-85.

Higgins, D. G. \& Sharp, P. M. (1989). Fast and sensitive multiple sequence alignments on a microcomputer. CABIOS 5, 151-153.

Honda, D., Yokota, A. \& Sugiyama, J. (1999). Detection of seven major evolutionary lineages in cyanobacteria based on the $16 \mathrm{~S}$ rRNA gene sequence analysis with new sequences of five marine Synechococcus strains. J Mol Evol 48, 723-739.

Hultman, T., Bergh, S., Moks, T. \& Uhlen, M. (1991). Bi-directional solid-phase sequencing of in vitro-amplified DNA. BioTechniques 10, 84-93.

Kenyon, C. N., Rippka, R. \& Stanier, R. Y. (1972). Fatty acid composition and physiological properties of some filamentous blue-green algae. Arch Microbiol 83, 216-236.

Kimura, M. (1980). A simple model for estimating evolutionary rates of base substitutions through comparative studies of nucleotide sequences. $J$ Mol Evol 16, 11-120.

Komárek, J. (1991). A review of water-bloom forming Microcystis species, with regard to population from Japan. Arch Hydrobiol Suppl 73 (Algol Stud 43), 115-127.

Komárek, J. \& Anagnostidis, K. (1989). Modern approach to the classification system of Cyanophytes, 4-Nostocales. Arch Hydrobiol Suppl 82 (Algol Stud 56), 247-345.

Kondo, R., Takashi, Y., Yasutaka, Y. \& Hiroshi, S. (2000). DNA-DNA reassociation among a bloom-forming cyanobacterial genus, Microcystis. Int J Syst Evol Microbiol 50, 767-770.

Kotai, J. (1972). Instructions for Preparation of Modified Nutrient Solution Z8 for Algae, Publication B-11/69. Blindern, Oslo: Norwegian Institute for Water Research.

Krishnamurthy, T., Carmichael, W. W. \& Saver, E. W. (1986). Toxic peptides from freshwater cyanobacteria (blue-green algae). Isolation, purification and characterization of peptides from Microcystis aeruginosa and Anabaena flos-aquae. Toxicon 24, 865-873.

Kuiper-Goodman, T., Falconer, I. \& Fitzgerald, J. (1999). Human health aspects. In Toxic Cyanobacteria in Water. A Guide to their Public Health Consequences, Monitoring and Management, pp. 113-153. Edited by I. Chorus \& J. Bartram. London: E \& FN Spon on behalf of WHO.

Lachance, M.-A. (1981). Genetic relatedness of heterocystous cyanobacteria by deoxyribonucleic acid-deoxyribonucleic acid reassociation. Int J Syst Bacteriol 31, 139-147.

Leeuwangh, P., Kappers, F. I., Dekker, M. \& Koerselman, W. (1983). Toxicity of cyanobacteria in Dutch lakes and reservoirs. Aquat Toxicol 4, 63-72.

Lehtimäki, J., Sivonen, K., Luukkainen, R. \& Niemelä, S. I. (1994). The effects of incubation time, temperature, light, salinity, and phosphorus on growth and hepatotoxin production by Nodularia strains. Arch Hydrobiol 130, 269-282.

Lehtimäki, J., Lyra, C., Suomalainen, S., Sundman, P., Rouhiainen, L., Paulin, L., Salkinoja-Salonen, M. \& Sivonen, K. (2000). Characterization of Nodularia strains, cyanobacteria from 
brackish waters, by genotypic and phenotypic methods. Int $J$ Syst Evol Microbiol 50, 1043-1053.

Lu, W., Evans, E. H., McColl, S. M. \& Saunders, V. A. (1997). Identification of cyanobacteria by polymorphism of PCRamplified ribosomal DNA spacer region. FEMS Microbiol Lett 153, 141-149.

Luukkainen, R., Sivonen, K., Namikoshi, M., Färdig, M., Rinehart, K. L. \& Niemelä, S. I. (1993). Isolation and identification of eight microcystins from thirteen Oscillatoria agardhii strains and structure of a new microcystin. Appl Environ Microbiol 59, 2204-2209.

Luukkainen, R., Namikoshi, M., Sivonen, K., Rinehart, K. L. \& Niemelä, S. I. (1994). Isolation and identification of 12 microcystins from four strains and two bloom samples of Microcystis spp.: structure of a new hepatotoxin. Toxicon 32, 133-139.

Lyra, C., Hantula, J., Vainio, E., Rapala, J., Rouhiainen, L. \& Sivonen, K. (1997). Characterization of cyanobacteria by SDSPAGE of whole-cell proteins and PCR/RFLP of the 16S rRNA gene. Arch Microbiol 168, 176-184.

Masepohl, B., Görlitz, K. \& Böhmen, H. (1996). Long tandemly repetitive (LTRR) sequences in the filamentous cyanobacterium Anabaena sp. PCC 7120. Biochim Biophys Acta 1307, 26-30.

Mazel, D., Houmard, J., Castets, A. M. \& Tandeau de Marsac, N. (1990). Highly repetitive DNA sequences in cyanobacterial genomes. J Bacteriol 172, 2755-2761.

Mullins, T. D., Britschgi, T. B., Krest, R. L. \& Giovannoni, S. J. (1995). Genetic comparisons reveal the same unknown bacterial lineages in Atlantic and Pacific bacterioplankton communities. Limnol Oceanogr 40, 148-158.

Nei, M. (1987). Molecular Evolutionary Genetics. New York: Columbia University Press.

Nei, M. \& Li, W.-H. (1979). Mathematical model for studying genetic variation in terms of restriction endonucleases. Proc Natl Acad Sci US A 76, 5269-5273.

Neilan, B. A., Jacobs, D. \& Goodman, A. E. (1995). Genetic diversity and phylogeny of toxic cyanobacteria determined by DNA polymorphisms within phycocyanin locus. Appl Environ Microbiol 61, 3875-3883.

Neilan, B. A., Jacobs, D., del Dot, T., Blackall, L. L., Hawkins, P. R., Cox, P. T. \& Goodman, A. E. (1997a). rRNA sequences and evolutionary relationships among toxic and nontoxic cyanobacteria of the genus Microcystis. Int J Syst Bacteriol 47, 693-697.

Neilan, B. A., Stuart, J. L., Goodman, A. E., Cox, P. T. \& Hawkins, P. R. (1997b). Specific amplification and restriction polymorphisms of the cyanobacterial rRNA operon spacer region. Syst Appl Microbiol 20, 612-621.

Neilan, B. A., Dittmann, E., Rouhiainen, L., Bass, R. A., Schaub, V., Sivonen, K. \& Börner, T. (1999). Non-ribosomal peptide synthesis and the toxigenicity of cyanobacteria. $J$ Bacteriol 181, 4089-4097.

Otsuka, S., Suda, S., Li, R., Watanabe, M., Oyaizu, H., Matsumoto, S. \& Watanabe, M. M. (1998). 16S rDNA sequences and phylogenetic analyses of Microcystis strains with and without phycoerythrin. FEMS Microbiol Lett 164, 119-124.

Otsuka, S., Suda, S., Li, R., Watanabe, M., Oyaizu, H., Matsumoto, S. \& Watanabe, M. M. (1999). Phylogenetic relationships between toxic and non-toxic strains of the genus Microcystis based on $16 \mathrm{~S}$ to $23 \mathrm{~S}$ internal transcribed spacer sequence. FEMS Microbiol Lett 172, 15-21.

Palinska, K. A., Liesack, W., Rhiel, E. \& Krumbein, W. E. (1996). Phenotype variability of identical genotypes: the need for a combined approach in cyanobacterial taxonomy demonstrated on Merismopedia-like isolates. Arch Microbiol 166, 224-233.

van de Peer, Y. \& de Wachter, R. (1994). TREECON for windows: a software package for the construction and drawing of evolutionary trees for the Microsoft Windows environment. Comput Applic Biosci 10, 569-570.

Rapala, J., Sivonen, K., Luukkainen, R. \& Niemelä, S. I. (1993). Anatoxin-a concentration in Anabaena and Aphanizomenon under different environmental conditions and comparison of growth by toxic and non-toxic Anabaena-strains - a laboratory study. J Appl Phycol 5, 581-591.

Rasmussen, U. \& Svenning, M. M. (1998). Fingerprinting of cyanobacteria based on PCR with primers derived from short and long tandemly repeated repetitive sequences. Appl Environ Microbiol 64, 265-272.

Ressom, R., Soong, F. S., Fitzgerald, J., Turczynowich, L., El Saadi, O., Roder, D., Maynard, T. \& Falconer, I. (1994). Health Effects of Toxic Cyanobacteria (Blue-Green Algae), pp. 1-108. Canberra: Australian Government Publishing Service.

Rippka, R. \& Herdman, M. (1992). Pasteur Culture Collection of Cyanobacterial Strains in Axenic Culture. Catalogue \& Taxonomic Handbook, Volume I: Catalogue of Strains, 1992/1993. Paris: Institute Pasteur.

Rippka, R., Deruelles, J., Waterbury, J. B., Herdman, M. \& Stanier, R. Y. (1979). Generic assignments, strain histories and properties of pure cultures of cyanobacteria. J Gen Microbiol 111, 1-61.

Rouhiainen, L., Sivonen, K., Buikema, W. J. \& Haselkorn, R. (1995). Characterization of toxin-producing cyanobacteria by using an oligonucleotide probe containing a tandemly repeated heptamer. J Bacteriol 177, 6021-6026.

Rudi, K. \& Jakobsen, K. S. (1999). Complex evolutionary patterns of tRNA ${ }^{\mathrm{Leu}}$ (UAA) group I introns in cyanobacterial radiation. $J$ Bacteriol 181, 3445-3451.

Rudi, K., Skulberg, O. M., Larsen, F. \& Jakobsen, K. S. (1997). Strain characterization and classification of oxyphotobacteria in clone cultures on the basis of $16 \mathrm{~S}$ rRNA sequences from the variable regions V6, V7, and V8. Appl Environ Microbiol 63, 2593-2599.

Rudi, K., Skulberg, O. M. \& Jakobsen, K. S. (1998). Evolution of cyanobacteria by exchange of genetic material among phyletically related strains. J Bacteriol 180, 3454-3461.

Saitou, N. \& Nei, M. (1987). The neighbor-joining method: a new method for reconstructing phylogenetic trees. Mol Biol Evol 4, 406-425.

Schmidt, T. M., DeLong, E. F. \& Pace, N. R. (1991). Analysis of a marine picoplankton community by $16 \mathrm{~S}$ rRNA gene cloning and sequencing. J Bacteriol 173, 4371-4378.

Sivonen, K. \& Jones, G. (1999). Cyanobacterial toxins. In Toxic Cyanobacteria in Water. A Guide to their Public Health Consequences, Monitoring and Management, pp. 41-111. Edited by I. Chorus \& J. Bartram. London: E\&FN Spon on behalf of WHO.

Sivonen, K., Himberg, K., Luukkainen, R., Niemelä, S. I., Poon, G. K. \& Codd, G. A. (1989). Preliminary characterization of neurotoxic cyanobacteria blooms and strains from Finland. Toxic Assess 4, 339-352.

Sivonen, K., Carmichael, W. W., Namikoshi, M., Rinehart, K., Dahlem, A. M. \& Niemelä, S. (1990). Isolation and characterization of hepatotoxic microcystin homologs from the filamentous freshwater cyanobacterium Nostoc sp. strain 152. Appl Environ Microbiol 56, 2650-2657.

Sivonen, K., Namikoshi, M., Evans, W. R., Carmichael, W. W., Sun, 
F., Rouhiainen, L., Luukkainen, R. \& Rinehart, K. L. (1992). Isolation and characterization of a variety of microcystins from seven strains of the cyanobacterial genus Anabaena. Appl Environ Microbiol 58, 2495-2500.

Sivonen, K., Namikoshi, M., Luukkainen, R., Färdig, M., Rouhiainen, L., Evans, W. R., Carmichael, W. W., Rinehart, K. L. \& Niemelä, S. (1995). Variation of cyanobacterial hepatotoxins in Finland. In The Contaminants in the Nordic Ecosystems. Dynamics, Processes \& Fate. Ecovision World Monograph Series, pp. 163-169. Edited by M. Munavar \& M. Luotola. Amsterdam: SPB Academic Publishing.

Sneath, P. H. A. \& Sokal, R. R. (1973). Numerical Taxonomy: the Principles and Practice of Numerical Classification. San Francisco: Freeman.

Stackebrandt, E. \& Goebel, B. M. (1994). Taxonomic note: a place for DNA-DNA reassociation and 16S rRNA sequence analysis in the present species definition in bacteriology. Int $J$ Syst Bacteriol 44, 846-849.

Starmach, K. (1966). In Flora Slodkowodna Polski, Cyanophyta Sinice, vol. 2, Warsaw: Glaucophyta-glaukofify.

Tikkanen, T. (1986). Kasviplanktonopas. Suomen luonnonsuojeluliiton tuki OY. Forssa: Forssan kirjapaino.

Turner, S. (1997). Molecular systematics of oxygenic photosynthetic bacteria. Plant Syst Evol 11, 13-52.

Turner, S., Pryer, K., Miao, V. \& Palmer, J. (1999). Investigating deep phylogenetic relationships among cyanobacteria and plastids by small subunit rRNA sequence analysis. $J$ Eukaryot Microbiol 46, 327-338.

Urbach, E., Scanlan, D. J., Distel, D. L., Waterbury, J. B. \& Chisholm, S. W. (1998). Rapid diversification of marine picophytoplankton with dissimilar light-harvesting structures inferred from sequences of Prochlorococcus and Synechococcus. $J$ Mol Evol 16, 188-201.

Versalovic, J., Koeuth, T. \& Lupski, J. R. (1991). Distribution of repetitive DNA sequences in eubacteria and application to fingerprinting of bacterial genomes. Nucleic Acids Res 19, 6823-6831.
Vezie, C., Brient, L., Sivonen, K., Bertru, G., Lefeuvre, J.-C. \& Salkinoja-Salonen, M. (1998). Variation of microcystin content of cyanobacterial blooms and isolated strains in lake GrandLieu (France). Microb Ecol 35, 126-135.

Vinuesa, P., Rademaker, J. L. W., de Bruijn, F. J. \& Werner, D. (1998). Genotypic characterization of Bradyrhizobium strains nodulating endemic woody legumes of the Canary Islands by PCR-restriction fragment length polymorphism analysis of genes encoding 16S rRNA (16S rDNA) and 16S-23S rDNA intergenic spacers, repetitive extragenic palindromic PCR genomic fingerprinting and partial $16 \mathrm{~S}$ rDNA sequencing. Appl Environ Microbiol 64, 2096-2104.

Ward, D. M., Bateson, M. M., Weller, R. \& Ruff-Roberst, A. L. (1992). Ribosomal RNA analysis of microorganisms as they occur in nature. Adv Microb Ecol 12, 219-286.

Wayne, L. G., Brenner, D. J., Colwell, R. R. \& 9 other authors (1987). International Committee on Systematic Bacteriology. Report of the ad hoc committee on reconciliation of approaches to bacterial systematics. Int J Syst Bacteriol 37, 463-464.

Weisburg, W. G., Barns, S. M., Pelletier, D. A. \& Lane, D. J. (1991). $16 \mathrm{~S}$ ribosomal DNA amplification for phylogenetic study. $J$ Bacteriol 173, 697-703.

Wilmotte, A. (1994). Molecular evolution and taxonomy of the cyanobacteria. In The Molecular Biology of Cyanobacteria, pp. 1-25. Edited by D. A. Bryant. Dordrecht: Kluwer.

Wilmotte, A., Turner, S., van de Peer, Y. \& Pace, N. R. (1992). Taxonomic study of marine oscillatoriacean strains (cyanobacteria) with narrow trichomes. II. Nucleotide sequence analysis of the $16 \mathrm{~S}$ ribosomal RNA. $J$ Phycol 28, 828-838.

Wilson, K. M., Schembri, M. A., Baker, P. D. \& Saint, C. P. (2000). Molecular characterization of the toxic cyanobacterium Cylindrospermopsis raciborskii and design of a species-specific PCR. Appl Environ Microbiol 66, 332-338.

Woese, C. R. (1987). Bacterial evolution. Microbiol Rev 51, 221-271.

Yasuno, M., Sugaya, Y., Kaya, K. \& Watanabe, M. (1998). Variations in the toxicity of Microcystis species to Moina macrocarpa. Phys Res Suppl 46, 31-36. 